\title{
Critical-Thinking Pedagogy and Student Perceptions of University Contributions to Their Academic Development
}

\author{
Martine Robinson Beachboard and John C. Beachboard \\ Idaho State University, Pocatello, ID, USA
}

\author{
beacmart@isu.edu; beach@isu.edu
}

\begin{abstract}
Colleges and universities are increasingly being called upon to demonstrate that they are indeed educating students and to justify the increasing tuition fees they charge (Education Consortium, 2006). Using data collected as part of the 2005 National Survey of Student Engagement (NSSE), this study examines the relationship between the assignment of higher order thinking activities during programs of study and student perceptions of the extent to which their universities have contributed to their general academic development and job preparation. The empirical evidence provided by this study indicates that the extra efforts faculty exert to engage their students in higher order thinking activities make a difference and are acknowledged, at least implicitly, by students as contributing to the development of critical life skills.
\end{abstract}

Keywords: higher order thinking, critical thinking, complexity, literacy, job preparedness, academic development.

\section{Introduction}

To educate students for democracy, we must educate them to deal with a future we do not (and cannot) know. Democratic life is unfolding (progressing) and a democratic education must therefore be an education in thinking through complex problems, developing the mind toward specific aims and goals, and learning to be reflective about the paths we choose.

$\sim$ Elmborg (2006, p. 5) on Dewey's educational philosophy

Many sectors of society, including government and industry, are expressing increased concerns about whether U.S. higher education is preparing students to meet the challenges they will face in the $21^{\text {st }}$ Century (Department of Education, 2006; Education Consortium, 2006). The concern is not just economic; observers critical of capitalist societies also have expressed dissatisfaction with the performance of higher education when it comes to helping citizens develop the critical

Material published as part of this publication, either on-line or in print, is copyrighted by the Informing Science Institute. Permission to make digital or paper copy of part or all of these works for personal or classroom use is granted without fee provided that the copies are not made or distributed for profit or commercial advantage AND that copies 1) bear this notice in full and 2) give the full citation on the first page. It is permissible to abstract these works so long as credit is given. To copy in all other cases or to republish or to post on a server or to redistribute to lists requires specific permission and payment of a fee. Contact 0HPublisher@InformingScience.org to request redistribution permission. thinking skills necessary to increase democratization and better prepare young people to assume responsible roles in society (Costa, 1985; Croteau \& Hoynes, 2002; Dewey, 1997; Kellner, 2004; Leveranz \& Tyner, 1993).

Deficiencies in educational outcomes among college graduates have been reported in terms of critical thinking, writing, problem-solving, effective professional performance and contribution to 
society (Department of Education, 2006; Education Consortium, 2006; Hart, 2006; NLCLEAP, 2007). While there will always be grounds for methodological debate, strong empirical evidence depicting a substantive decline in the literacy skills of four-year-college graduates has been reported (Kutner et al., 2007). Colleges and universities are increasingly being called upon to demonstrate that they are indeed educating students and to justify the increasing tuition fees they charge (Education Consortium, 2006).

As faculty members with extensive work experience, we share the concerns expressed above. We have wrestled with the pedagogical challenges associated with helping students to improve their critical thinking and communication skills. In the face of competing demands on their time, faculty members must carefully assess whether the benefits student derive from completing assignments intended to develop higher order thinking (HOT) skills outweigh the costs. University administrators and future employers might reasonably ask, "What costs? Isn't that what university faculty are hired to do: help student to 'think' better?" The reality is that university faculty tenure and promotion tend to be based more on research productivity than on teaching evaluations. The extensive use of HOT assignments can significantly increase the time teachers spend mentoring students and grading assignments (cutting into faculty research productivity) and meet with (sometimes fierce) student resistance (particularly when students are held to high standards on completing written assignments).

Multiple streams of literature address what we view to be related domains of critical thinking and literacy; they offer a variety of prescriptions concerning how to improve thinking and communication skills. Yet relatively little, large-scale, empirical research has been performed to test whether the use of these methods does reliably improve student learning outcomes. Accordingly, this research seeks to answer the three related research questions:

RQ1. Does increasing assignments related to the development of higher order thinking skills lead to improved general academic development?

RQ2. Does increasing assignments related to the development of higher order thinking skills lead to improved job preparation?

RQ3. Does increasing assignments related to the development of higher order thinking skills lead to improved grades?

Using data collected as part of the 2005 National Survey of Student Engagement (NSSE), this study examines the relationship between the assignment of higher order thinking activities encountered during programs of study and student perceptions of the extent to which their universities have contributed to their general academic development and job preparation after controlling for a variety of potentially confounding variables. The following sections provide an overview of literature relating to the conceptualization of critical thinking and literacy, describe the research methodology employed, present findings based on the analysis of data collected, and finally discuss theoretical and practical implications resulting from our analysis and interpretation of the reported findings.

\section{Literature Review}

Why don't you just tell me what you want me to do? I don't want to have to think!

A student's complaint, made to the first author in response to an assignment in a mass communication class, is indicative of the challenges faced by teachers in higher education and represents part of the problem motivating the formulation of this study. How do educators instill in students a desire to think? For logically if there is no desire to think, it becomes much more challenging to improve the critical thinking of college graduates. 
An extensive literature describes pedagogical techniques that teachers may employ to improve their students' critical thinking and communication skills. However, an unfortunate result of specialized academic disciplines is the balkanization of research streams addressing closely related phenomena. Accordingly, we present literature related to information literacy and critical thinking, believing these two general research streams strongly complement one another.

Beyond the general conceptualization of literacy as an ability to read and write, researchers have defined and investigated numerous types of literacy including: computer, cultural, digital, functional, media, and visual (Aufderheide, 1993; Eisenberg, Lowe, \& Spitzer Kathleen, 2004; Elmborg, 2006; Hobbs, 1996; Kellner, 2004; D. Moore \& Dwyer, 1994). An overarching conceptualization of information literacy is adequate for the purposes of this study. The library and information science community defines this literacy in terms of what an information-literate person can do. He or she is one who (Doyle, 1994; Eisenberg et al., 2004):

- recognizes accurate and complete information as the basis for intelligent decision making

- formulates questions based on information needs

- identifies potential sources of information

- develops successful search strategies

- accesses sources of information including computer-based and other technologies

- evaluates information

- organizes information for practical application

- integrates new information into an existing body of knowledge

- uses information in critical thinking and problem solving

A comprehensive conceptualization of information literacy is further emphasized in this call to incorporate information literacy across the educational curriculum: "To become effective information users, students must have frequent opportunities to handle all kinds of information. Locating, interpreting, analyzing, synthesizing, evaluating, communicating information should become a part of every subject across the curriculum" (AASL, 1995, p. 22).

Given the disciplinary background of most information literacy researchers, their concept of literacy tends to emphasize the identification of information needs and information-seeking behavior more than how information is actually used. While this area does recognize the importance of information evaluation, it is rather weak at describing the attributes of critical thinking or judgment processes necessary to consider the quality of information desired and to apply information obtained. Yet the information-seeking and -valuing processes are critical to the conduct of critical thinking.

Perry proposed a model depicting how students come to know things, the beliefs they hold about knowing, and how their epistemological premises influence their cognitive processes (Hofer \& Pintrich, 1997, p. 88). The Perry Scheme of Intellectual and Ethical Development (Perry, 1970) was developed from extensive qualitative analysis of more than 400 interviews conducted primarily with Harvard undergraduates in the 1950's and 1960's. Perry described students as developing through nine stages from "primarily intellectual-systematic, cognitive-structural... toward increasing differentiation and complexity of thinking... [to] 'ethical' in the classical Greek sense issues of identity and personal meaning-making in an ambiguous, relativistic world" (W. S. Moore, 1995). Four major categories provide an overview of Perry's sequence: dualism, multiplicity, contextual relativism, and commitment within relativism (W. S. Moore, 1995). Even more recently, King and Kitchener (1994) developed their model of reflective judgment with seven levels of thinking whose development they said may take to the age of 30 to occur. Their idea of 
reflective judgment calls on learners to examine their own biases and to acknowledge various epistemological perspectives.

Recent literature on critical thinking explicitly has addressed the cognitive processes associated with applying information and recognizing the uncertainty inherent in making judgments. It addresses the ability to evaluate arguments and evidence and to construct rationales for beliefs as well as examination of one's own reasoning (Bruning, 1994). Two distinct perspectives have been employed in the investigation of critical thinking (King \& Kitchener, 1994). One perspective focuses on the development of logical reasoning and the ability to properly formulate logical arguments and draw logically correct inductive and deductive inferences (Salmon, 1989). The second and predominant perspective in the literature conceives of critical thinking as reflective judgment and is characterized as an inquiry or problem-solving process where a demonstrably correct solution cannot be identified.

A report for the American Philosophical Association (Facione, 1990) describes a comprehensive conceptualization of critical thinking based on the results of a Delphi study of international experts asked to form a consensus about the meaning of critical thinking. These experts concluded: "We understand critical thinking to be purposeful, self-regulated judgment which results in interpretation, analysis, evaluation, and inference, as well as explanation of the evidential, conceptual, methodological, criteriological, or contextual considerations upon which that judgment is based." To fully appreciate this definition, some explanation of its key terms, representing critical thinking skills, is useful. These include (Facione, 2007, pp. 4-7,21):

- Interpretation. To comprehend and express the meaning or significance of a wide variety of situations, experiences, data, events, judgments, conventions, beliefs, rules, procedures, or criteria.

- Analysis. To identify the intended and actual inferential relationships among statements, questions, concepts, descriptions or other forms of representation intended to express beliefs, judgments, experiences, reasons, information, or opinions.

- Evaluation. To assess the credibility of statements or other representations that are accounts or descriptions of a person's perception, experience, situation, judgment, belief, or opinion; and to assess the logical strength of actual or intended inferences among statements, descriptions, questions, or other forms of representation.

- Inference. To identify and secure elements needed to draw reasonable conclusions; to form conjectures and hypotheses; to consider relevant information and educe [draw out] the consequences flowing from data, statements, principles, evidence, judgments, beliefs, opinions, concepts, descriptions, questions or other forms of representation.

- Explanation. To state and to justify one's reasoning in terms of the evidential, conceptual, methodological, criteriological, and contextual considerations upon which one's results were based; and to present one's reasoning in the form of cogent arguments.

- Self-regulation. Self consciously to monitor one's cognitive activities, the elements used in those activities, and the results educed, particularly by applying skills in analysis and evaluation to one's own inferential judgments with a view toward questioning, confirming, validating, or correcting one's reasoning or results.

Of primary significance to this study were prescriptions from this body of research for developing critical thinking skills. Critical thinking as a process of inquiry is constructivist in its orientation, and thus researchers in this tradition are sensitive to environmental/social impact on student learning (King \& Kitchener, 1994, 2004; Wolcott, 2006). Community learning or formal cohort 
programs are believed to facilitate the interaction and peer learning is thought to promote critical thinking and contextual learning skills (Bredemeier, 1998; MacGregor, 1991).

A set of activities explicitly associated with improvement in higher order thinking skills has been incorporated into the National Survey of Student Engagement instrument. These include the student's assessment of the extent to which his or her assignments emphasized:

- analyzing the basic elements of an idea, experience, or theory, such as examining a particular case or situation

- working on papers or projects that required integrating ideas or information from various sources

- putting together ideas or concepts from different courses when completing assignments or during class discussion

- synthesizing and organizing ideas, information, or experiences into new, more complex interpretations and relationships

- making judgments about the value of information, arguments or methods, such as examining how others gathered and interpreted data, and assessing the soundness of their conclusions

- examining the strengths and weaknesses of one's own views on a topic or issue

From the literature, it is clear that successful development of information literacy and critical thinking implicitly requires high levels of performance in reading - to locate and access relevant information - and in written or oral skills - to explain the methods and results of one's thinking. This literature informed the selection of NSSE items to be included in this study's academic development construct; these items address student assessments of the extent to which their universities contributed to their ability to:

- write clearly and effectively

- speak clearly and effectively

- think critically and analytically

learn effectively on their own

The first two pertain especially to literacy, the latter two to critical thinking.

Figure 1 presents the conceptual model upon which the study hypotheses were framed. Key vari-
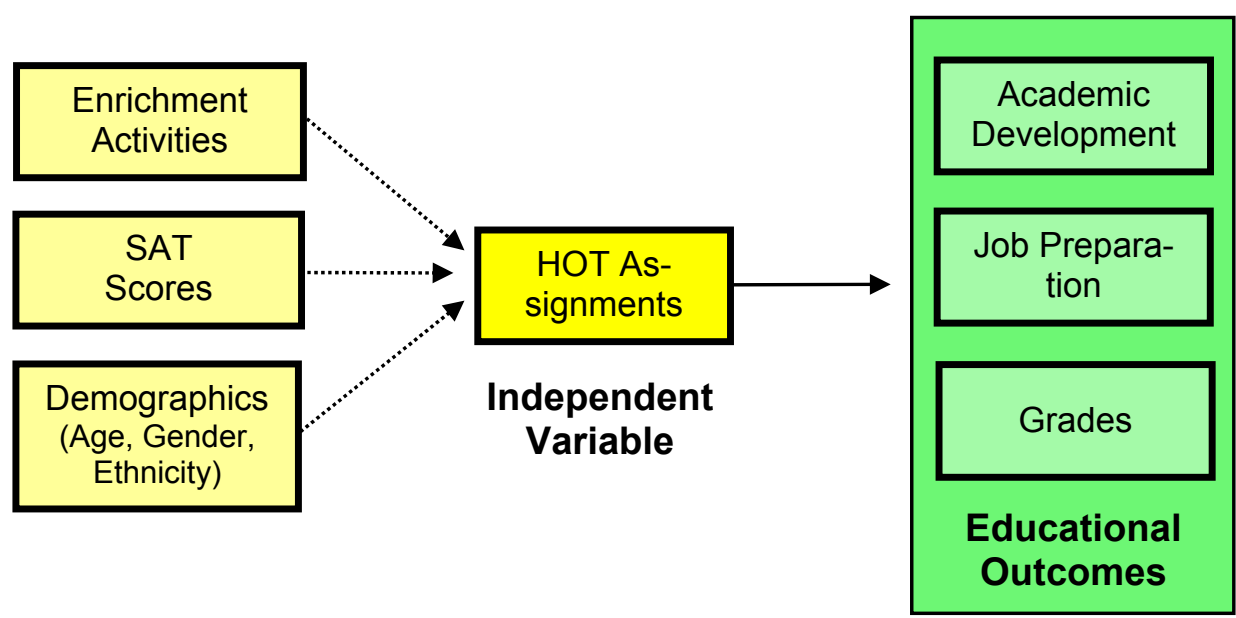

\section{Control Variables}

Figure 1. Research Model

\section{Dependent Variables}


ables used in this study and their types and operationalization are explained in Table 1. As explained in the methodology section, all constructs were derived from data collected as part of the 2005 NSSE, a copy of which is available in the Appendix.

Table 1 briefly describes how study variables were constructed. The description includes the item numbers from the NSSE 2005 survey instrument (see Appendix). We combined participation in multiple enrichment activities into a single variable (ENRICH) to control for student participation in activities considered to be academically productive: internship/practicum, community service, formal learning community, and conducting research with a faculty member.

Table 1. Identification and Operationalization of Variables

\begin{tabular}{|c|c|c|c|}
\hline Variable Name & $\begin{array}{l}\text { Cronbach } \\
\text { Alpha }\end{array}$ & Operationalization of Variable & $\begin{array}{l}\text { NSSE } \\
\text { Question* }\end{array}$ \\
\hline \multicolumn{4}{|l|}{ Independent variables } \\
\hline $\begin{array}{l}\text { Higher order thinking as- } \\
\text { signments (HOT) }\end{array}$ & .762 & $\begin{array}{l}\text { Respondent's indication of having participated in or } \\
\text { been assigned activities related to analysis, synthe- } \\
\text { sis, or evaluation of information or ideas. Measure- } \\
\text { ments used Likert scales of student's perception of } \\
\text { degree or frequency of assignment. }\end{array}$ & $\begin{array}{l}1 \mathrm{~d} \\
1 \mathrm{i} \\
2 \mathrm{~b} \\
2 \mathrm{c} \\
2 \mathrm{~d} \\
6 \mathrm{~d}\end{array}$ \\
\hline \multicolumn{4}{|l|}{ Dependent variables } \\
\hline Grades (GRADE) & $\mathrm{n} / \mathrm{a}$ & $\begin{array}{l}\text { Student's report of what most grades have been so } \\
\text { far at this institution. }\end{array}$ & 25 \\
\hline $\begin{array}{l}\text { Academic development } \\
\text { (ACADEV) }\end{array}$ & .825 & $\begin{array}{l}\text { Combined measure of respondent's perception of } \\
\text { extent of institution's contribution to his/her writing, } \\
\text { speaking, critical thinking, and independent-learning } \\
\text { ability. Measurement used a Likert scale. }\end{array}$ & $\begin{array}{l}11 \mathrm{c} \\
11 \mathrm{~d} \\
11 \mathrm{e} \\
11 \mathrm{j}\end{array}$ \\
\hline $\begin{array}{l}\text { Job preparation } \\
\text { (JOBPREP) }\end{array}$ & .727 & $\begin{array}{l}\text { Combined measure of respondent's perception of } \\
\text { institution's contribution to his/her job- or work- } \\
\text { related knowledge and skills. Measurement used a } \\
\text { Likert scale. }\end{array}$ & $\begin{array}{l}11 \mathrm{~b} \\
11 \mathrm{~h} \\
11 \mathrm{~m}\end{array}$ \\
\hline \multicolumn{4}{|l|}{ Control variables } \\
\hline $\begin{array}{l}\text { Enrichment activities } \\
\text { (ENRICH) }\end{array}$ & $\mathrm{n} / \mathrm{a}$ & $\begin{array}{l}\text { Survey respondent's indication of having partici- } \\
\text { pated in educational activities thought to be associ- } \\
\text { ated with improved learning outcomes. Binary } \\
\text { measures for participation in each activity have been } \\
\text { aggregated. }\end{array}$ & $\begin{array}{l}7 \mathrm{a} \\
7 \mathrm{~b} \\
7 \mathrm{c} \\
7 \mathrm{~d}\end{array}$ \\
\hline SAT scores (SAT) & $\mathrm{n} / \mathrm{a}$ & $\begin{array}{l}\text { Survey respondent's incoming freshman SAT score } \\
\text { (or ACT score converted to SAT equivalent) as re- } \\
\text { ported by participating institution. }\end{array}$ & $\mathrm{n} / \mathrm{a}$ \\
\hline $\begin{array}{l}\text { Parent educational level } \\
\text { (PARENTED) }\end{array}$ & & Highest level of education attained by parents. & 27 \\
\hline $\begin{array}{l}\text { Demographic/Age (AGE - } \\
\text { Dichotomized) }\end{array}$ & (categorical) & $\begin{array}{l}\text { Respondent's age in years as reported by participat- } \\
\text { ing institution. }\end{array}$ & $\mathrm{n} / \mathrm{a}$ \\
\hline $\begin{array}{l}\text { Demographic/Gender } \\
\text { (GENDER) }\end{array}$ & (categorical) & Respondent's self-reported gender identification. & 16 \\
\hline $\begin{array}{l}\text { Demographic/Ethnicity } \\
\text { (ETHNIC - Dichotomized) }\end{array}$ & (categorical) & $\begin{array}{l}\text { Respondent's self-reported racial or ethnic identifi- } \\
\text { cation. }\end{array}$ & 18 \\
\hline
\end{tabular}

* Numbers identify questions from 2005 NSSE instrument available at Appendix.

\section{Hypotheses}

Based on an analysis of relevant literature, hypotheses were proposed to address the relationships between the major independent variables of cohort participation and higher order thinking assignments and the dependent variables, which consisted of selected measures of educational outcomes. There is a one-to-one relationship between the research questions and the hypotheses. 
H1. Institutional emphasis on higher order thinking assignments contributes to improved academic development.

H2. Institutional emphasis on higher order thinking assignments contributes to improved job preparation.

H3. Institutional emphasis on higher order thinking assignments contributes to improved grades.

\section{Methodology}

This study performed secondary analysis of cross-sectional data collected by the National Survey of Student Engagement (NSSE). The NSSE is an annual questionnaire administered to college students to measure their participation in a variety of activities that prior research has shown to be positively related to desirable educational outcomes (Kuh, 2001, 2003). While behavior is reflected by students' responses to survey questions, NSSE's focus is on institutional rather than student assessment. Sufficient demographic information is included to determine whether participation in and effects of these various activities systematically vary among student subpopulations.

The NSSE data have been employed in numerous reports and scholarly articles, and there is ample evidence attesting to the validity and reliability of the research instrument (even though it has evolved somewhat, based on annual use, feedback and development) (Kuh, Kinzie, Cruce, Shoup, $\&$ Gonyea, 2007; McInnis, 2006). The 2005 version had 529 participating colleges and universities (NSSE, 2006).

The instrument relies on self-reports, a method some researchers may question; however, selfreports are likely to be valid if they meet five conditions: (1) information requested is known to respondents; (2) questions are phrased clearly and unambiguously; (3) questions refer to recent events; (4) respondents think questions merit thoughtful response; and (5) answering does not threaten or embarrass respondents (Bradburn \& Sudman, 1988; Pace, 1984; Pike, 1995). The NSSE authors state that their College Student Report "was intentionally designed to satisfy all these conditions" (NSSE, 2007).

\section{Respondent Characteristics}

Agreements established between the Indiana University Center for Postsecondary Research and participating institutions place some restrictions on the use of data by external researchers. Therefore, rather than having access to the full 2005 NSSE dataset, we were given access to a sample of just 2,000 records randomly drawn from the larger dataset. The NSSE administrators provided a stratified sample of cases for this study, selected to meet the following student and institutional criteria:

- Gender (half male, half female).

- Class-level status (seniors only, who are better positioned to assess institutional contribution to academic development and job preparation).

- Full-time student status.

- Non-international (to reduce confounding factors of cultural differences and to eliminate small cell sizes).

- Cohort or learning community status, half having participated, half not. (This selection criterion was used in support of a separate study.)

- Carnegie institution type II and III public institutions (to reduce heterogeneity of campus cultures and socioeconomics). 
These parameters reduced the available population of relevant records to 50,562 from which 2,000 were randomly selected. These came from 130 of the 529 participating four-year colleges and universities.

Based on an analysis of the descriptive statistics for our original sample size, we made two further restrictions to our data set. The great majority of college seniors in the data sample (1,934 out of the data set of 2,000) were in the age range of 20 to 29. However, seven responses were from seniors younger than 20,57 were from seniors older than 30, and 2 were unknown). Given their extremely small cell sizes, we excluded the latter outlier data and divided the age demographic variable into two useful groups: $20-23$ and 24-29. Also, due to relatively small cell sizes, we dichotomized the ethnicity variable yielding white (non-Hispanic) and non-white categories. This approach necessitated the further removal of records associated with the unknown and "other" responses to the ethnicity question because it was impossible to knowledgeably classify these students into one of the two major ethnic categories. The results of all these manipulations eliminated 148 records from the original dataset, leaving 1,852. Table 2 depicts the frequency breakdowns associated with these decisions.

Table 2. Frequencies and Percentages for Categorical Variables

\begin{tabular}{lcc}
\hline $\begin{array}{l}\text { Student Characteristics } \\
\text { Gender }\end{array}$ & $\mathrm{N}$ & $\%$ \\
\hline Male & 920 & $49.68 \%$ \\
Female & 932 & $50.32 \%$ \\
Ethnicity & & \\
\hline White & 1538 & $83.05 \%$ \\
Other & 314 & $16.95 \%$ \\
Age & & \\
\hline $20-23$ & 1626 & $12.20 \%$ \\
$24-p l u s$ & 226 & \\
\hline Total & 1,852 usable records \\
\hline
\end{tabular}

\section{Analytic Approach}

We employed OLS regression models to test the research hypotheses. Separate regression models were run for each DV. Because study objectives were practical as well as theoretical, we tested multiple hierarchical regression models to tease out and control the influence of confounding variables while reporting the main effects in a clear and useful manner given the level of covariance observed between our endogenous and selected exogenous variables.

\section{Research Findings}

Tables 3, 4, and 6 report the results of hierarchical regression analyses performed on the three selected dependant variables: academic development, job preparation, and grades. 
Table 3. Results of Hierarchical Regression Model with Academic Development as Dependent Variable and HOT as Independent Variable $(N=1836)$

\begin{tabular}{|c|c|c|c|c|}
\hline Models & Independent Variable(s) & $\mathrm{B}$ & $\beta$ & Sig. \\
\hline \multicolumn{5}{|c|}{ Model 1} \\
\hline & Constant & 12.730 & & $* * *$ \\
\hline & Gender & 0.393 & 0.074 & $* * *$ \\
\hline & SAT & -0.001 & -0.074 & $* *$ \\
\hline & Age & -0.329 & -0.048 & Ns \\
\hline & Ethnicity & 0.344 & 0.048 & $*$ \\
\hline & Enrichment & 0.437 & 0.169 & $* * *$ \\
\hline & Parental Education & -0.014 & -0.015 & Ns \\
\hline \multicolumn{5}{|c|}{ Model 2} \\
\hline & Constant & 7.451 & & $* * *$ \\
\hline & Gender & 0.325 & 0.061 & $* *$ \\
\hline & SAT & -0.002 & -0.110 & $* * *$ \\
\hline & Age & -0.456 & -0.056 & $* *$ \\
\hline & Ethnicity & 0.212 & 0.030 & Ns \\
\hline & Enrichment & 0.133 & 0.052 & $*$ \\
\hline & Parental Education & -.040 & -0.042 & $*$ \\
\hline & Higher order thinking & 0.363 & 0.442 & $* * *$ \\
\hline
\end{tabular}

$* * * \mathrm{p} \leq .001, * * \mathrm{p} \leq .01, * \mathrm{p} \leq .05, \mathrm{~ns}=$ nonsignificant.

Model 1: $\mathrm{R}^{2}=.050$. Model 2: $\mathrm{R}^{2}=.229, \Delta \mathrm{R}^{2}=.179$.

Results reported in Table 3 provide evidence in support of research hypothesis 1 . The regression coefficient for higher order thinking as a predictor of academic development is statistically significant $(\beta=0.442, p<.001)$. The control variables account for five percent of variance explained. The addition of higher order thinking contributed almost 18 percent to the variance explained.

Results reported in Table 4 provide evidence in support of research hypothesis 2 . The regression coefficient for higher order thinking as a predictor of job preparation is statistically significant $(\beta=0.376, p<.001)$. The control variables account for approximately 5.6 percent of variance explained. The addition of higher order thinking contributed 13 percent to the variance explained. 
Table 4. Results of Hierarchical Regression Model with Job Preparation as Dependent Variable and HOT as Independent Variable $(N=1836)$

\begin{tabular}{llccl} 
Models & Independent Variable(s) & B & $\beta$ & Sig. \\
\hline Model 1 & & & & \\
& Constant & 9.501 & & $* * *$ \\
& Gender & 0.184 & 0.044 & $\mathrm{~ns}$ \\
& SAT & -0.001 & -0.067 & $* *$ \\
& Age & -0.485 & -0.077 & $*$ \\
& Ethnicity & 0.023 & 0.004 & $\mathrm{~ns}$ \\
& Enrichment & 0.400 & 0.199 & $* * *$ \\
& Parental Education & -0.008 & -0.011 & $\mathrm{~ns}$ \\
\hline \multirow{2}{*}{ Model 2 } & & & & \\
& Constant & 6.004 & & $* * *$ \\
& Gender & 0.138 & 0.033 & $\mathrm{~ns}$ \\
& SAT & -0.001 & -0.097 & $* * *$ \\
& Age & -0.570 & -0.090 & $* * *$ \\
& Ethnicity & -0.059 & -0.011 & $\mathrm{~ns}$ \\
& Enrichment & 0.199 & 0.099 & $* * *$ \\
Parental Education & -0.025 & -0.034 & $\mathrm{~ns}$ \\
Higher order thinking & 0.240 & 0.376 & $* * *$ \\
\hline
\end{tabular}

$* * * \mathrm{p} \leq .001, * * \mathrm{p} \leq .01,{ }^{*} \mathrm{p} \leq .05, \mathrm{~ns}=$ nonsignificant. Model 1: $\mathrm{R}^{2}=.056$. Model 2: $\mathrm{R}^{2}=.186, \Delta \mathrm{R}^{2}=.13$.

\section{Discussion and Implications}

Before proceeding with the discussion of the primary study findings, it is useful to revisit the selection of the DVs - student perceptions of institutional contributions to their general academic development and job preparation and their grades - and briefly discuss their unique strengths and weaknesses in terms of the objectives of this research. This study includes no direct measurement of student academic performance in the areas of critical thinking and communication. Grades are somewhat objective measures of academic performance but often reflect a student's ability to regurgitate memorized information on exams as much as, or more than, student ability to communicate or think effectively. Furthermore, it is the opinion of this research team and others (Merrow, 2007) that grades are becoming less and less of an indicator of academic development due to grade inflation and compression in recent years. This critique of the conventional quantitative grading system seems particularly justified since grades are rising while SAT scores are falling. However, grades were an obvious choice for a dependent variable because they remain common currency in the realm of academe and are readily available and easily analyzed along with the other variables.

The DVs of most interest to us were academic development and job preparation. The description of these constructs is admittedly ungainly. In emphasizing student perceptions of institutional 
contributions to their academic development and job preparation, these constructs are two steps removed from being an objective measure. But from a policy-making perspective, student perceptions of institutional contributions to their development can provide the basis for action, either by individual faculty or institutions of higher education.

Given the conceptual distinction between the grades DV and the academic development and job preparation DVs, it should not be surprising that the relative strength of the CVs and IV in explaining grades variance relative to academic development and job preparation variance was dramatically different, with grades apparently much more susceptible to CV influence. This is depicted in Table 5, which provides a compact overview of how much the IV, HOT, influenced the DVs in contrast with the CVs.

Table 5. CV and IV Relative Contributions to Variance Explained in DV

\begin{tabular}{llll}
\hline & $\mathrm{R}^{2}: \mathrm{CVs}$ & $\mathrm{R}^{2}: \mathrm{CVs}$ \\
Dependent Variable & Only & $\Delta \mathrm{R}^{2}$ & $\& \mathrm{HOT}$ \\
\hline Academic Development & $5.0 \%$ & $17.9 \%$ & $22.9 \%$ \\
Job Preparation & $5.6 \%$ & $13.0 \%$ & $18.6 \%$ \\
Grades & $16.4 \%$ & $0.8 \%$ & $17.2 \%$ \\
\hline
\end{tabular}

For grades, the CVs explained more than 16 percent of variance while the higher order thinking assignments explained less than one percent. In contrast, for the academic development and job preparation DVs, the CVs explain approximately five percent of variance.

The higher order thinking assignments IV proved to be a much stronger predictor of academic development and job preparation - DVs of more substantive interest in this study. Data from this study strongly confirm the results predicted by critical thinking models identified in the literature review. Increased higher order thinking assignments did consistently correlate with improvement in all three DVs: academic development, job preparation, and grades, although the correlation for grades was not high. The addition of higher order thinking to the regression model added almost 18 percent to the amount of variance explained for academic development and 13 percent for job preparation. These findings were consistent with prescriptive literature emanating from critical thinking and literacy research. Many people, including the authors, would argue that these are inextricably intertwined (Ennis, 1985; Glaser, 1985; King \& Kitchener, 1994; Lipman, 1988; Perry, 1981; Wolcott, 2006).

The more limited contribution of higher order thinking activities to grades makes sense. Students who have largely mastered the skills of rote learning emphasized in much course work might be rewarded with good grades but perform more modestly in courses where greater emphasis is placed on the development of the higher order skills of critical thinking.

For educators and administrators in charge of policy and curriculum, this study's results support the increased use of higher order thinking techniques where there is substantive interest in improving students' critical thinking abilities. Anecdotal evidence based on the researchers' own teaching experiences and conversations with colleagues indicates that many students are uncomfortable with courses that heavily emphasize writing and unstructured problem-solving. Faced with student resistance and the fact that designing and grading such assignments is more difficult, instructors might be reluctant to employ these types of assignments without some assurance that the effort will be beneficial. Whether or not students consciously realize that their responses indicate a strong association between their participation in higher order learning activities and their perceptions of institutional contributions to their academic evidence and job preparation, the evidence appears to be quite compelling. Consistent with previous prescriptive literature on literacy and critical thinking, institutions should encourage their faculty to incorporate higher order thinking activities into their course designs. 
Table 6. Results of Hierarchical Regression Model with Grades as Dependent Variable and HOT as Independent Variable $(N=1838)$

\begin{tabular}{lllll} 
Models & Independent Variable(s) & B & B & Sig. \\
\hline
\end{tabular}

Model 1

\begin{tabular}{|c|c|c|c|c|}
\hline & Constant & 1.678 & & $* * *$ \\
\hline & Gender & 0.431 & 0.135 & $* * *$ \\
\hline & SAT & 0.003 & 0.319 & $* * *$ \\
\hline & Age & 0.025 & 0.005 & ns \\
\hline & Ethnicity & -0.444 & -0.103 & $* * *$ \\
\hline & Enrichment & 0.260 & 0.168 & $* * *$ \\
\hline & Parental Education & -0.004 & -0.007 & ns \\
\hline \multicolumn{5}{|l|}{ Model 2} \\
\hline & Constant & .991 & & $* * *$ \\
\hline & Gender & 0.423 & 0.132 & $* * *$ \\
\hline & SAT & 0.003 & 0.311 & $* * *$ \\
\hline & Age & 0.007 & 0.067 & ns \\
\hline & Ethnicity & -0.460 & -0.107 & $* * *$ \\
\hline & Enrichment & 0.221 & 0.142 & $* * *$ \\
\hline & Parental Education & -0.007 & -0.012 & ns \\
\hline & Higher order thinking & 0.047 & 0.096 & $* * *$ \\
\hline
\end{tabular}

$* * * \mathrm{p} \leq .001, * * \mathrm{p} \leq .01,{ }^{*} \mathrm{p} \leq .05, \mathrm{~ns}=$ nonsignificant.

Model 1: $\mathrm{R}^{2}=.164$. Model 2: $\mathrm{R}^{2}=.172, \Delta \mathrm{R}^{2}=.008$.

Results reported in Table 6 provide evidence in support of research hypothesis 3 . The regression coefficient for higher order thinking as a predictor of grades is statistically significant $(\beta=0.096$, $\mathrm{p}<.001)$. In the case of grades, the control variables account for over 16 percent of variance explained. The addition of higher order thinking contributed less than one percent to the variance explained.

\section{Limitations of This Research}

It is important to acknowledge the limitations associated with this study's research design. These limitations include:

- The NSSE instrument itself relied exclusively on student self-reports (although participating institutions provided some additional data such as SAT and ACT scores). However, researchers have provided evidence supporting the validity of self-reports under certain conditions as discussed in the Methodology description above.

- The potential for method bias exists. In commenting on the results of previous research employing NSSE data, Pike (2006) noted that use of a common method to measure the IVs and DVs can be problematic. 
- The lack of random assignment of students to education with and without higher levels of higher order thinking assignments eliminates the use of statistical controls to minimize the chances of relevant, unmeasured factors confounding the findings.

- This study used cross-sectional data in support of a causal argument. Thus, the study's findings should be cautiously interpreted and applied.

- Given restraints on the sampling frame, the results of this study should be validly generalizable to programs and students at public Carnegie II and III institutions (students who are U.S. citizens within the specified age range).

\section{Conclusion}

This study does support the proposition that increasing the number of higher order thinking assignments in a program of study does correlate with, if not predict, students perceiving greater institutional contributions to their general academic development and job preparation. The findings had considerable face validity and were largely consistent with the literature on literacy and critical thinking. The empirical evidence provided by this study is gratifying because it indicates that the extra efforts that faculty exert to engage their students in higher order thinking activities make a difference and are acknowledged, at least implicitly, by students as contributing to their development of critical life skills.

When Informing Science was first proposed (Cohen, 2009) the focus was on how information systems performed or informed specific tasks. More recently, the focus of the transdiscipline has been extended to include more complex, less routine activities where task boundaries are not clear and task participants need to explicitly consider uncertainty and other stakeholders' points of view (Gill \& Cohen, 2008). Consistent with the increasing social and economic challenges to be faced by participants in modern democratic societies, where the "task" to be performed involves adapting to a turbulent and continuously evolving environment, the emphasis of informing necessarily moves away from an absolute reliance on factual knowledge toward engaging students in activities that increase their adaptability - the development of higher order thinking skills being a primary example.

\section{References}

AASL. (1995). Information literacy: A position paper on information problem-solving. Emergency Librarian, 20-23.

Aufderheide, P. (1993). Media literacy: A report of the national leadership conference on media literacy. Queenstown, MD: Aspen Institute.

Bradburn, N., \& Sudman, S. (1988). Polls and surveys: Understanding what they tell us. San Francisco: Jossey-Bass.

Bredemeier, H. (1998). Experience vs. understanding: Understanding yourself in twenty-first century societies. London, UK: Transactions.

Bruning, R. (1994). The college classroom from the perspective of cognitive psychology. In K. Prichard \& R. Sawyer (Eds.), Handbook of college teaching. Westport, CT: Greenwood Press.

Cohen, E. B. (2009). A philosophy of informing science. Informing Science: the International Journal of an Emerging Transdiscipline, 12, 1-15. Retrieved from http://www.inform.nu/Articles/Vol12/ISJv12p001-015Cohen399.pdf

Costa, A. (1985). Developing minds: A resource book for teaching thinking. Alexandria, VA: Association for Supervision and Curriculum Development.

Croteau, D., \& Hoynes, W. (2002). Media/society: Industries, images and audiences (3rd ed.). Thousand Oaks, CA: Pine Forge Press. 
Department of Education. (2006). The Secretary of Education's Commission on the future of higher education. In A test of leadership: Charting the future of U.S. higher education. Washington, DC: Education Publication Center.

Dewey, J. (1997). Democracy and education: An introduction to the philosophy of education. New York, NY: The Free Press.

Doyle, C. (1994). Information literacy in an information society: A concept for the information age. Syracuse, NY: ERIC Clearinghouse on Information and Technology.

Education Consortium. (2006). Are they really ready to work? Employers' perspectives on the basic knowledge and applied skills of new entrants to the 21 st century U.S. workforce. U.S.A.: The Conference Board, Inc., Partnership for 21st Century Skills, Corporate Voices for Working Families and the Society for Human Resource Management.

Eisenberg, M. B., Lowe, C. A., \& Spitzer Kathleen, L. (2004). Information literacy: Essential skills for the information age. Westport, CT: Libraries Unlimited.

Elmborg, J. (2006). The other Dewey. In G. Gibson (Ed.), Student engagement and information literacy (pp. 1-15). U.S.A.: Association of College and Research Libraries.

Ennis, R. (1985). Critical thinking and the curriculum. National Forum, 65(1), 28-31.

Facione, P. (Ed.) (1990). Critical thinking: A statement of expert consensus for the purposes of educational assessment and instruction [ERIC ED 315 423]. American Philosophical Association. Millbrae, CA: California Academic Press

Facione, P. (2007). Critical thinking: What it is and why it counts. Retrieved 30 December 2007, from Insite Assessment.com: http://www.insightassessment.com/pdf files/what\&why2006.pdf.

Gill, T. G., \& Cohen, E. B. (2008). Research themes in complex informing. Informing Science: the International Journal of an Emerging Transdiscipline, 11, 147-164. Retrieved from http://www.inform.nu/Articles/Vol11/ISJv11p147-164GillIntro.pdf

Glaser, E. (1985). Critical thinking: Educating for responsible citizenship in a democracy. National Forum, 65(1), 24-27.

Hart, P. D. (2006). Report of findings: Based on focus groups among business executives: Conducted on Behalf of: The Association of American Colleges and Universities. 31 January 2006. Retrieved 17 November 2007, from Association of American Colleges and Universities: http://www.aacu.org/advocacy/leap/documents/Re8097abcombined.pdf

Hobbs, R. (1996). Expanding the concept of literacy. In R. Kubey (Ed.), Media literacy in the information age: Information and behavior (pp. 163-183). Transaction Publishers.

Hofer, B., \& Pintrich, P. (1997, Spring). The development of epistemological theories: Beliefs about knowledge and knowing and their relation to learning. Review of Educational Research, 67(1), 88-140.

Kellner, D. (2004). Technological transformation, multiple literacies, and the re-visioning of education. $E$ Learning, 1(1), 9-37.

King, P. M., \& Kitchener, K. S. (1994). Developing reflective judgment: Understanding and promoting intellectual growth and critical thinking in adolescents and adults. San Francisco, CA: Jossey-Bass.

King, P. M., \& Kitchener, K. S. (2004). Reflective judgment: Theory and research on the development of epistemic assumptions through adulthood. Educational Psychologist, 39(1), 5-18.

Kuh, G. D. (2001). Assessing what really matters to student learning outcomes: Inside the National Survey of Student Engagement. Change, 33(3), 10-17, 66.

Kuh, G. D. (2003). What we are learning about student engagement from NSSE. Change, 35(2), 24-32.

Kuh, G. D., Kinzie, J., Cruce, T., Shoup, R., \& Gonyea, R. M. (2007). Connecting the dots: Multi-faceted analyses of the relationships between student engagement results from the NSSE, and the institutional 
practices and conditions that foster student success. Retrieved 29 November 2007, from NSSE Institute: http://nsse.iub.edu/pdf/Connecting the_Dots_Report.pdf

Kutner, M., Greenberg, E., Jin, Y., Boyle, Hsu, Y.-c., Dunleavy, E., \& White, S. (2007). Literacy in everyday life: Results from the 2003 assessment of adult literacy. U.S. Department of Education: Washington, DC, April 2007. Retrieved 17 November 2007, from Institute of Education Sciences, National Center for Education Statistics: http://nces.ed.gov/pubsearch/pubsinfo.asp?pubid=2007480

Leveranz, D., \& Tyner, K. (1993, August/September). Inquiring minds want to know: What is media literacy. The Independent, 21-25.

Lipman, M. (1988). Critical thinking: What can it be? Educational Leadership, 45(1), 38-43.

MacGregor, J. (1991). What differences do learning communities make? Washington Center News, 6, 4-9.

McInnis, E. D. (2006). Nonresponse bias in student assessment surveys: A comparison of respondents and non-respondents of the National Survey of Student Engagement at an independent comprehensive Catholic university. Unpublished doctoral dissertation, Marywood University, College of Education and Human Development.

Merrow, J. (2007). Grade inflation: It's not just an issue for the Ivy League. Retrieved from The Carnegie Foundation for the Advancement of Teaching: http://www.carnegiefoundation.org/perspectives/sub.asp?key=245\&subkey $=576$

Moore, D., \& Dwyer, F. (1994). Visual literacy: A spectrum of visual learning. Englewood Cliffs, NJ: Educational Technology Publications.

Moore, W. S. (1995). My mind exploded: Intellectual development as a critical framework for understanding and assessing collaborative learning. In Assessment in and of Collaborative Learning Environments. Olympia, WA: Washington Center for Improving Undergraduate Education.

NLCLEAP. (2007). College learning for the new global century. Washington, DC: The Association of American Colleges and UniversitiesRetrieved 17 November 2007, retrieved from http://www.aacu.org/advocacy/leap/documents/GlobalCentury final.pdf

NSSE. (2006). Exploring different dimensions of student engagement: 2005 annual survey results Retrieved 20 October 2007, from http://nsse.iub.edu/pdf/NSSE2005 annual_report.pdf

NSSE. (2007). 2002 psychometric framework. In National Survey of Student Engagement. Retrieved 1 May 2008, from Indiana University Center for Postsecondary Research: http://nsse.iub.edu/html/psychometric_framework_2002.cfm

Pace, C. (1984). Measuring the quality of student experiences. Los Angeles, CA: University of California, Higher Education Research Institute.

Perry, W. G. (1970). Forms of intellectual and ethical development in the college years: A scheme. New York: Holt, Rinehart \& Winston.

Perry, W. G. (1981). Cognitive and ethical growth: The making of meaning. In A. Chickering \& Associates (Eds.), The modern American college (pp. 76-116). San Francisco: Jossey-Bass.

Pike, G. (1995). The relationships between self reports of college experiences and achievement test scores. Research in Higher Education, 36, 1-22.

Pike, G. R. (2006, September/October). The convergent and discriminant validity of NSSE scalelet scores. Journal of College Student Development, 47(5), 551-564.

Salmon, M. (1989). Logic and critical thinking. Orlando, FL: Harcourt Brace Jovanovich.

Wolcott, S. K. (2006). College faculty handbook: Steps for better thinking. Introduces steps for better thinking. Unpublished. First draft availableswolcott@wolcottlynch.com 


\section{Appendix. NSSE Instrument}

\section{National Survey of Student Engagement 2005 \\ The College Student Report}

In your experience at your institution during the current school year, about how often have you done each of the following? Mark your answers in the boxes. Examples: $邓$ or $\square$

a. Asked questions in class or contributed to class discussions

b. Made a class presentation

c. Prepared two or more drafts of a paper or assignment before turning it in

d. Worked on a paper or project that required integrating ideas or information from various sources

e. Included diverse perspectives (different races, religions, genders, political beliefs, etc.) in dass discussions or writing assignments

f. Come to class without completing readings or assignments

g. Worked with other students on projects during class

h. Worked with classmates outside of class to prepare class assignments

i. Put together ideas or concepts from different courses when completing assignments or during class disoussions

$$
\begin{aligned}
& \text { Very } \\
& \text { often Often times Never }
\end{aligned}
$$

f. Tutored or taught other students (paid or voluntary)

k. Participoted in a communitybased project (c.g., service learning) as part of a regular course

I. Used an electronic medium (listserv, chat group, intemet, instant messaging, etc.) to discuss or complete an assignment

m. Used e-mail to communicate with an instructor

n. Discussed grades or assignments with an instructor

o. Taked about career plans with a faculty member or advisor

p. Disoussed ideas from your readings or classes with faculty members outside of class

q. Recelved prompt feedback from faculty on your academic performance (written or oral) r. Worked harder than you thought you could to meet an instructor's standards or copectations

s. Worked with faculty members on activities other than coursework (committees, or ientation. student life activities, etc)

t. Discussed ideas from your readings or classes with others outside of class (students, family members, co-workers, etc)

u. Had serious conversations with tudents of a different race or ethnicity than your own

v. Had ser ious conversations with tudents who are very different from you in terms of their religious beliefs, political opinions, or personal values

Very some. fiten Often times Never

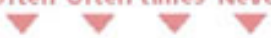

2 During the current school year, how much has your coursework emphasized the following mental activities?

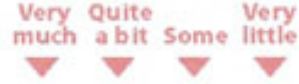

a. Memorizing facts, idcas, or methods from your courses and readings so you can repeat them in pretty much the same form

b. Analyzing the basic elcments of an idea, experience, or theory. such as examining a particular case or situation in depth and considering its components

c. Syntheslizing and organizing ideas, information, or experiences into new, more complex interpretations and relationship

d. Making judgments about the value of information, arguments, or methods, such as examining how others gathered and interpreted data and assessing the soundness of their condusions $\square \quad \square \quad \square \quad \square$

e. Applying thecries or concepts to practical problems or in new situations 


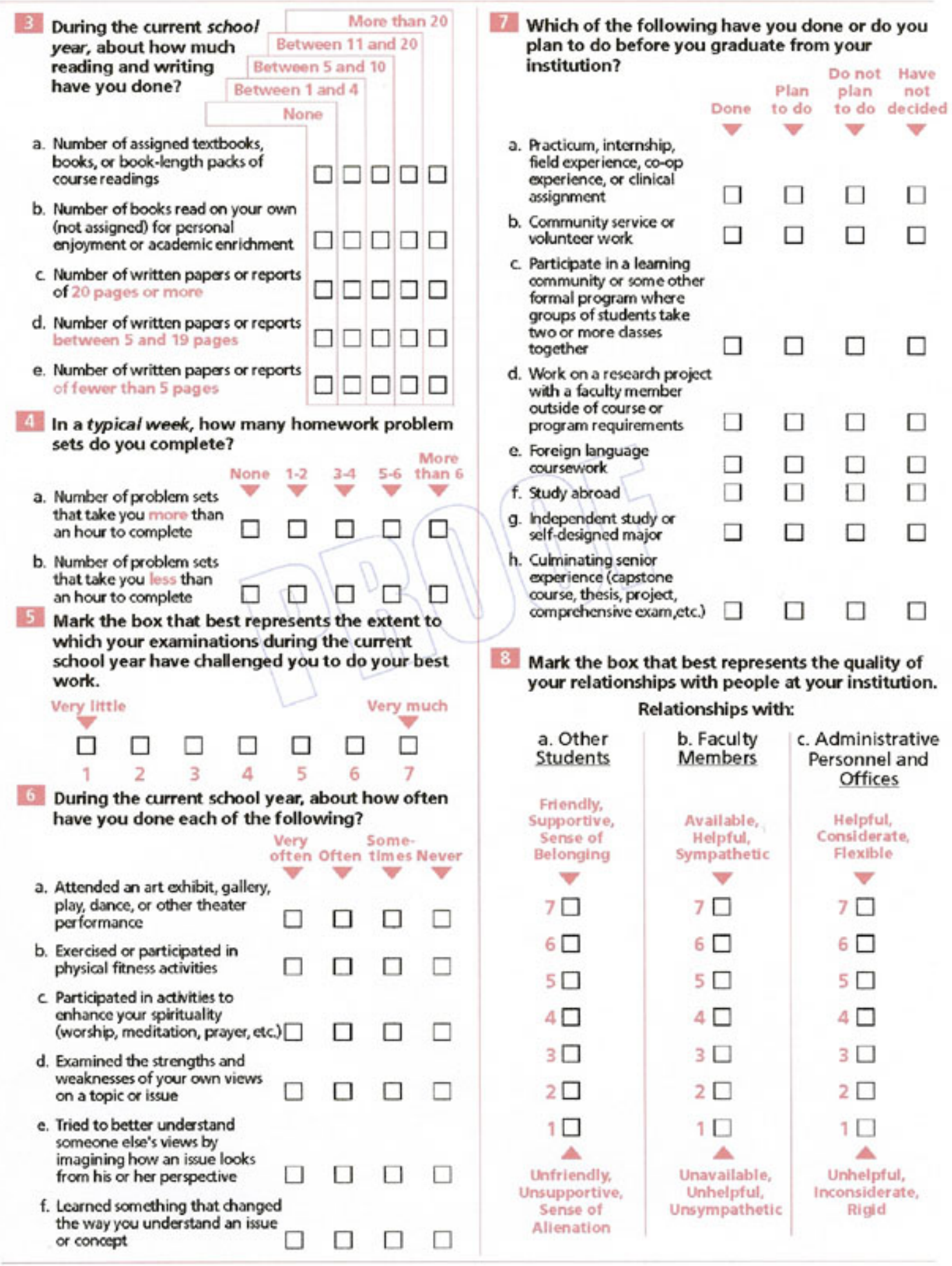




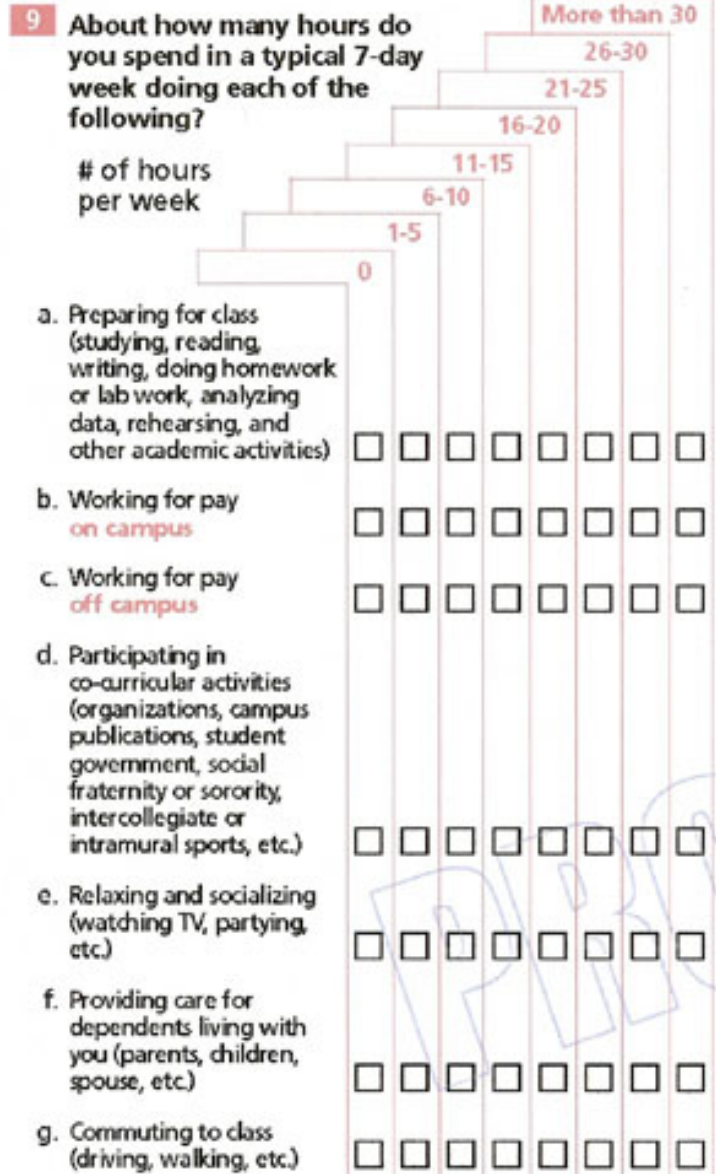

10 To what extent does your institution emphasize each of the following?

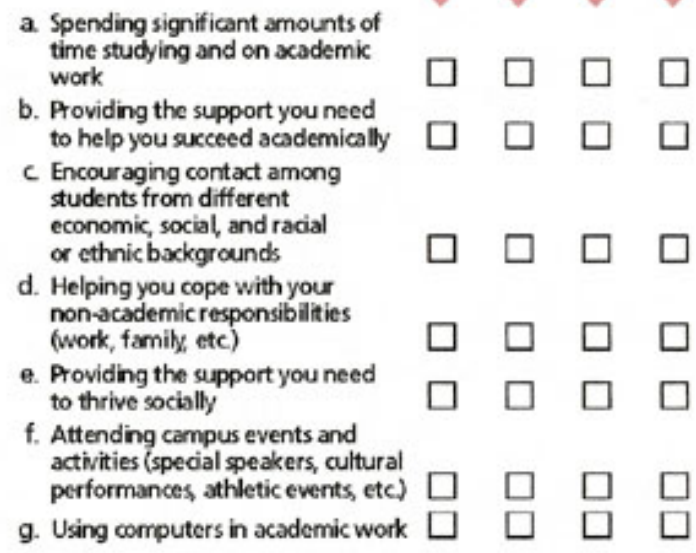

11 To what extent has your experience at this institution contributed to your knowledge, skills, and personal development in the following areas?

$$
\begin{aligned}
& \text { Very Quite } \\
& \text { much a bit some Iittle } \\
& \nabla
\end{aligned}
$$

a. Acquiring a broad general education

b. Acquiring job or work-related knowledge and skills

c. Writing dearly and effectively

d. Speaking dearly and effectively

e. Thinking critically and andytically

f. Analyzing quantitative problems

g. Using computing and information technology

h. Working effectivdy with others

i. Voting in local, state, or national election

j. Learning effectively on your own $\square \quad \square \quad \square \quad \square$

k. Understanding yourself

L. Understanding people of other radial and ethric backgrounds

m. Solving complex real-world problems

n. Developing a personal code of values and ethics

o. Contributing to the welfare of your community

p. Developing a decpened senee of spirituality

12 Overall, how would you evaluate the quality of academic advising you have received at your institution?

$\square$ Excellent

$\square$ Good

$\square$ Fair

$\square$ Poor

13 How would you evaluate your entire educational experience at this institution?
$\square$ Excellent
$\square$ Good
$\square$ Fair
$\square$ poor

14 If you could start over again, would you go to the same institution you are now attending?
$\square$ Definitelyyes
$\square$ Probablyyes
$\square$ Probably no
$\square$ Definitely no 


\section{Biographies}

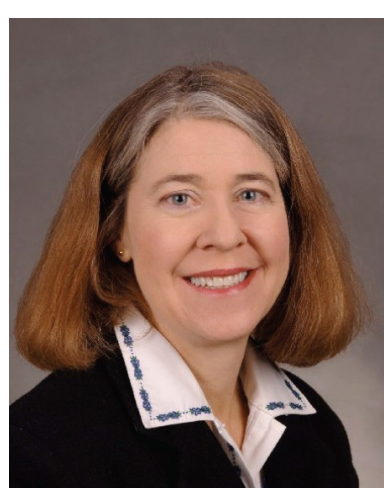

Martine Robinson Beachboard is an Associate Professor of Mass Communication at Idaho State University in Pocatello, ID. She teaches courses in advertising, public relations, and mass communication and society. Dr. Beachboard previously taught with the University of Maryland European Division. She has published in the areas of international and intercultural journalism. She is also interested in media literacy and critical thinking. She is a member of the Association for Education in Journalism and Mass Communication.

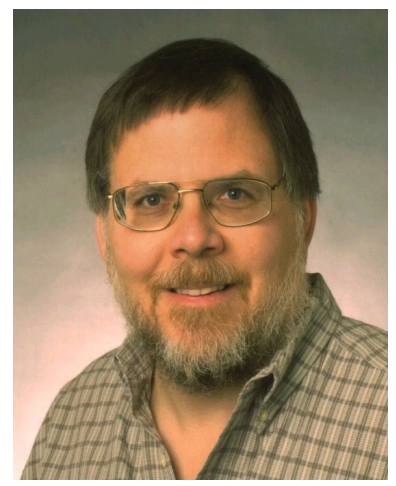

John Beachboard is professor of Computer Information Systems at Idaho State University. He has more than 25 years' experience implementing large-scale information technology and telecommunications systems and directing the Army's Data Network Control Center in Europe. In 2004, he received an AIS Award for Innovation in IS Education for his work incorporating IT service management concepts in the CIS curriculum at ISU. His teaching and research interests emphasize practical approaches for delivering and operating secure, cost-effective IT services. He is a member of AIS, ACM, and itSMF. 